\title{
Phyllosilicates in bottom sediments of Lake Baunt (northern Transbaikalia) as indicators of paleoclimate
}

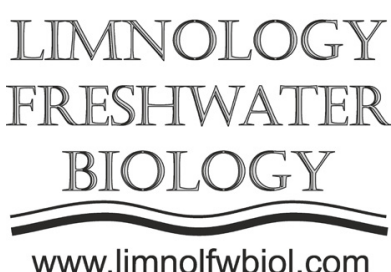

\author{
Solotchin P.A. ${ }^{1 *}$, Solotchina E.P. ${ }^{1}$, Bezrukova E.V. ${ }^{2,3,4}$, Zhdanova A.N. ${ }^{1}$ \\ ${ }^{1}$ V.S. Sobolev Institute of Geology and Mineralogy, Siberian Branch of the Russian Academy of Sciences, pr. Koptyuga, 3, Novosibirsk, \\ 630090, Russia \\ ${ }^{2}$ A.P. Vinogradov Institute of Geochemistry, Siberian Branch of the Russian Academy of Sciences, Favorskogo Str., 1a, Irkutsk, 664033 \\ Russia \\ ${ }^{3}$ Tyumen Industrial University, Volodarskogo Str, 38, Tyumen, 625000, Russia \\ ${ }^{4}$ Irkutsk Scientific Center, Siberian Branch of the Russian Academy of Sciences, Lermontov Str., 134, 664033, Russia
}

\begin{abstract}
The lacustrine sediments are unique natural archives that store records of environmental and climatic changes. We present results of study of the Late Pleistocene-Holocene sediments of freshwater Lake Baunt, located in the permafrost zone in northern Transbaikalia. The sediments were studied by X-ray diffraction (XRD), IR spectroscopy, laser granulometry, elemental analysis, AMS dating, etc. The results of mineral analysis of the bottom sediments with an age of $\sim 18$ ka showed that they are mainly represented by phyllosilicates, quartz, and feldspars. By the mathematical modeling of complex XRD patterns chlorite, muscovite, illite, mixed-layer illite-smectite and chlorite-smectite, and kaolinite identified among the phyllosilicates. It was established that variations of their structural features as well as quantitative proportions in the section are in high correlation with the climate changes and lake level fluctuations. The results obtained helped to reconstruct the evolution of the Lake Baunt basin controlled by the regional climate throughout the Late Pleistocene-Holocene.
\end{abstract}

Keywords: Bottom sediments, phyllosilicates, XRD analysis, paleoclimate, Transbaikalia, Lake Baunt

\section{Introduction}

The drastic changes in the Earth's climate and the uncertainty of its predictive models trigger interest in the Late Pleistocene-Holocene lacustrine sedimentary records, because the climatic conditions repeatedly changed in that period. Mineralogical and crystallochemical characteristics of the deposited phases bear important information, because their composition and structure depend directly on the chemical composition of lake waters, their salinity and temperature, and the biologic productivity of the paleobasin, which are in turn controlled by the regional climate. The goal of our work was to reconstruct the environment and climate of the northern Transbaikalia based on the study of composition and structures of minerals from bottom sediments of carbonate-free fresh lakes (by the example of Lake Baunt). Phyllosilicates, which are abundant in sediments of such lakes, can serve as indicator minerals.

\section{Materials and methods}

Lake Baunt is located in the northeast of the Republic of Buryatia, in the western part of the Baunt depression which belongs to the Baikal Rift Zone (Shchetnikov, 2007). The lake area is $111 \mathrm{~km}^{2}$, the average depth is $17 \mathrm{~m}$; the water is fresh (TDS $<250$ $\mathrm{mg} / \mathrm{L}, \mathrm{pH}=6.80-7.25$ ) and of calcium bicarbonate type. The object of study was the Bnt-14 core sediments to a depth of $800 \mathrm{~cm}$, with a sampling step of $5 \mathrm{~cm}$. A total of 142 samples were analyzed.

Lithological and mineralogical studies of the samples were carried out by X-ray diffractometry (XRD), IR spectroscopy, laser granulometry, and X-ray fluorescence spectrometry. A new level of research was reached by applying the author's effective technique of mathematical modeling of complex X-ray diffraction profiles of phyllosilicates (Solotchina et al., 2002; Solotchina, 2009). The AMS ${ }^{14} \mathrm{C}$ dating of the sediments was made in the Poznan Radiocarbon Laboratory (Poland). The measured values were converted to calendar ages.

\section{Results}

The studied section of the Lake Baunt bottom sediments has a clear two-unit structure. The depth range $0-540 \mathrm{~cm}$ is composed of massive diatom ooze with varying contents of silt material; the depth range 
$540-800 \mathrm{~cm}$ is formed predominantly by clay and silt with a sand admixture. The age of the studied bottom sediments (Krainov et al. 2017) is $~ 18,150$ cal yr BP, i.e., covers the entire Holocene and the latest Pleistocene. The major minerals of the Baunt bottom sediments are phyllosilicates; there are also feldspars, quartz, and traces of amphibole and pyrite.

It was found that phyllosilicates are composed of muscovite, illite, mixed-layer illite-smectites and chlorite-smectites, $14 \AA$-chlorite, and kaolinite. The content of well-crystallized muscovite varies greatly in the samples, from 53\% (Oldest Dryas) to $22 \%$ (Atlantic). The content of dispersed illite varies slightly throughout the section (from 25 to $18 \%$ ). The content of mixed-layer illite-smectites in the sediments varies most significantly, from 22 to $4 \%$ of the total phyllosilicates. The number of smectite layers in their structure varies from $20 \%$ (Oldest Dryas) to $40 \%$ (Atlantic and Bölling-Alleröd). The sediments also contain chlorite $(2.8-12.5 \%)$ and a fine mixed-layer chlorite-smectite ( $8 \%$ in the bottom to $22 \%$ in the roof of the section). In addition, all samples have a kaolinite admixture $(\sim 5 \%)$.

\section{Discussion and conclusions}

Comprehensive studies of the sediments of the freshwater Lake Baunt located in the continuouspermafrost zone gave an insight into the late Quaternary evolution of the environment and climate in northern Transbaikalia. The quantitative proportions of phyllosilicates in the section and their structural and crystal-chemical characteristics are the main indicators of climate change. The warming periods (Atlantic and Bölling-Alleröd) are marked by high contents of dispersed illite-smectite with the abundance of smectite (expandable) layers as well as illite and chlorite-smectite. The sediments of the cooling periods (Preboreal and Oldest Dryas), on the contrary, mark intensification of physical weathering and have high contents of well-crystallized detrital muscovite, chlorite, quartz, and feldspars. The content of illite layers in the illite-smectite structure also increases (up to $80 \%$ ). The results of the mineralogical study of the sediments are consistent with the behavior of geochemical indicators in the section and with the data of the earlier palynological high-resolution analysis of the Lake Baunt sediments from the Bnt-13 core (Bezrukova et al., 2017). The performed studies made it possible to reconstruct the evolution of the Lake Baunt basin controlled by the regional climate throughout the Late Pleistocene-Holocene.

The work is done on state assignments of IGM SB RAS and IG SB RAS and is also supported by grants 18-05-00329, 19-05-00219, and 19-05-00328 from the Russian Foundation for Basic Research. Most of the analytical studies were carried out at the Analytical Center for Multi-Elemental and Isotope Research SB RAS, Novosibirsk.

\section{References}

Bezrukova E.V., Amosova A.A., Chubarov V.M. et al. 2017. Environmental changes in the northeast of the Buryat Republic during the Holocene post-Optimum: First results. Contemporary Problems of Ecology 10: 431-440. DOI: 10.1134/S1995425517040011

Krainov M.A., Bezrukova E.V., Kerber E.V. et al. 2017. First results of study of Lake Baunt bottom sediments (northern Transbaikalia). Russian Geology and Geophysics 58: 1401-1411. DOI: 10.1016/j.rgg.2017.02.005

Shchetnikov A.A. 2007. Morphotectonics of lacustrine basins: The Baikal rift zone as an example. Russian Journal of Pacific Geology 1: 120-129. DOI: 10.1134/ S1819714007020029

Solotchina E.P. 2009. Structural typomorphism of clay minerals of sedimentary sections and crusts of weathering. Novosibirsk: Geo. (in Russian)

Solotchina E.P., Prokopenko A.A., Vasilevsky A.N. et al. 2002. Simulation of XRD patterns as an optimal technique for studying glacial and interglacial clay mineral associations in bottom sediments of Lake Baikal. Clay Minerals 37: 105-119. DOI:10.1080/0009855023710021 